At Alum Bay these beds have a thickness of $75 \mathrm{~m}$ which is reduced to $38 \mathrm{~m}$ at Bartonon-Sea. The succeeding Upper Barton Beds (Barton Sands and Headon Hill Sands, in the Isle of Wight) offer a good lithological contrast from the underlying clays. At present, it seems reasonable, therefore, to correlate our layer 2 with the Barton clays, with the layer 1/layer 2 interface marking the junction between the clays and the predominantly sandy lithology of the Upper Barton Beds. Layer 1 would consist of the Upper Barton Beds together with the varied lithologies of the Lower Headon Beds and the succeeding Oligocene strata, possibly upwards as far as the Osborne Beds.

These estimates of thickness may be subject to error due to unknown lateral variations both in lithology and in individual bed thickness. However, the estimates do indicate approximately the expected cumulative thickness within the area. More specific indentification of layers 1,2 and 3 should be possible when further information is obtained from velocities observed from outcrop shooting within the Hampshire Basin.

\title{
REFERENCES
}

BULlard, E. C., GASKELL, T. F., HARLAND, W. B. \& KERR-GRANT, C. 1940. Seismic investigations on the Palaeozoic floor of east England. Phil. Trans. R. Soc., A, 239, 29-44.

COOK, E. E. 1965. Geophysical operations in the North Sea. Geophysics, 30, $495-510$.

DAY, A. A., HILl, M. N., LAUGHTON, A. S. \& SWAllow, J. C. 1956. Seismic prospecting in the Western Approaches of the English Channel. Q. Jl geol. Soc. Lond., 112, 15-44.

GRIFFITHS, D. H., KING, R. F. \& WILSON, C. D. V. 1961. Geophysical investigations in Tremadoc Bay, North Wales. Q. Jl geol. Soc. Lond., 117, 171-191.

HILL, M. N. \& KING, W. B. R. 1953. Seismic prospecting in the English Channel and its geological interpretation. Q. Jl geol. Soc. Lond., 109, 1-18.

HODSON, F. \& SHELFORD, P. H. 1964. in 'A survey of Southampton and its region'; Ed. F. J. Monkhouse. Advmt Sci., London.

LAUGHTON, A. S. \& STRIDE, A. H. 1957. The velocity of compressional waves for a stratigraphic profile of chalk at Flamborough Head, Yorkshire. Nature Lond., $180,977-978$.

STRIDE, A. H. 1959. On the Origin of the Dogger Bank, in the North Sea. Geol. Mag., $96,33-44$.

WOOLDRIDGE, S. W. \& LINTON, D. L. 1955. Structure, surface and drainage in south-east England. Phillip \& Son, Ltd., London, 176 p.

K. R. DYER (1)

N. HAMILTON (2)

R. D. PINGREE (1)

(1) DEPARTMENT OF OCEANOGRAPHY,

(2) DEPARTMENT OF GEOLOGY,

THE UNIVERSITY,

SOUTHAMPTON.

21st October, 1968.

\section{A GRAVITY INTERPRETATION OF THE LIRUEI RING COMPLEX, NIGERIA}

SIR, -I should like to consider some implications of Miss Ajakaiye's most welcome paper (Geol. Mag., 105, 256-263). The finding of a pronounced negative anomaly was to be expected in the Liruei complex, which consists almost entirely of granitic rocks with only insignificant amounts of basic rocks exposed at the surface. The almost completely acidic nature of the Nigerian Younger Granite province has long been recognised from surface mapping. The geophysical evidence from Liruei now shows that these granitic ring-complexes are unlikely to be associated with large basic intrusions at depth. 
Theories on the origin of acid magma in similar igneous provinces-differentiation from a basic parent within the crust or high level melting adjacent to large bodies of basic magma-cannot therefore readily be applied to Nigeria.

The gravity survey indicates that the contacts of the Liruei granitic mass dip outwards at angles of $70^{\circ}$ and less. This appears to conflict with the field evidence, for the outer ring-dyke at Liruei and similar structures in other Nigerian ring-complexes are essentially vertical. Subsequent intrusions in many complexes have gently outward dipping contacts, but these are sometimes seen to steepen with depth and the outcrops are mainly confined within the initial ring-dyke, leading to the idea of a composite granite mass of generally cylindrical form (Turner, 1963). However, examination of maps of the ringcomplexes does show a number of cases where late intrusions, especially large plutons of biotite-granite with irregular shaped outcrops, overlap and partly obliterate the early peripheral ring-dyke or ring-fracture, suggesting non-vertical contacts (Fig.1). Also, in the extreme south of the province, where the Younger Granites are probably most deeply eroded, the Afu and Mada complexes lack the usual circular outcrop form. Thus a model for the deeper structures of the Nigerian ring-complexes is:-

(1) An early cylindrical structure, connected with surface volcanicity and caldera development, defined by a vertical ring-fracture or a ring-dyke, within which may be a series of ring-dykes and roofed cauldron-subsidence intrusions. Compositions include fayalite-hedenbergite-, riebeckite- and biotite-granites and minor syenites. Successive intrusions have smaller diameters, indicating diminishing magma volumes.

(2) Late massive intrusions of biotite-granite, not conforming to the early ring fracture pattern nor connected with volcanism. A body of this type, probably including the biotite-granite which outcrops in the centre of the Liruei complex, may

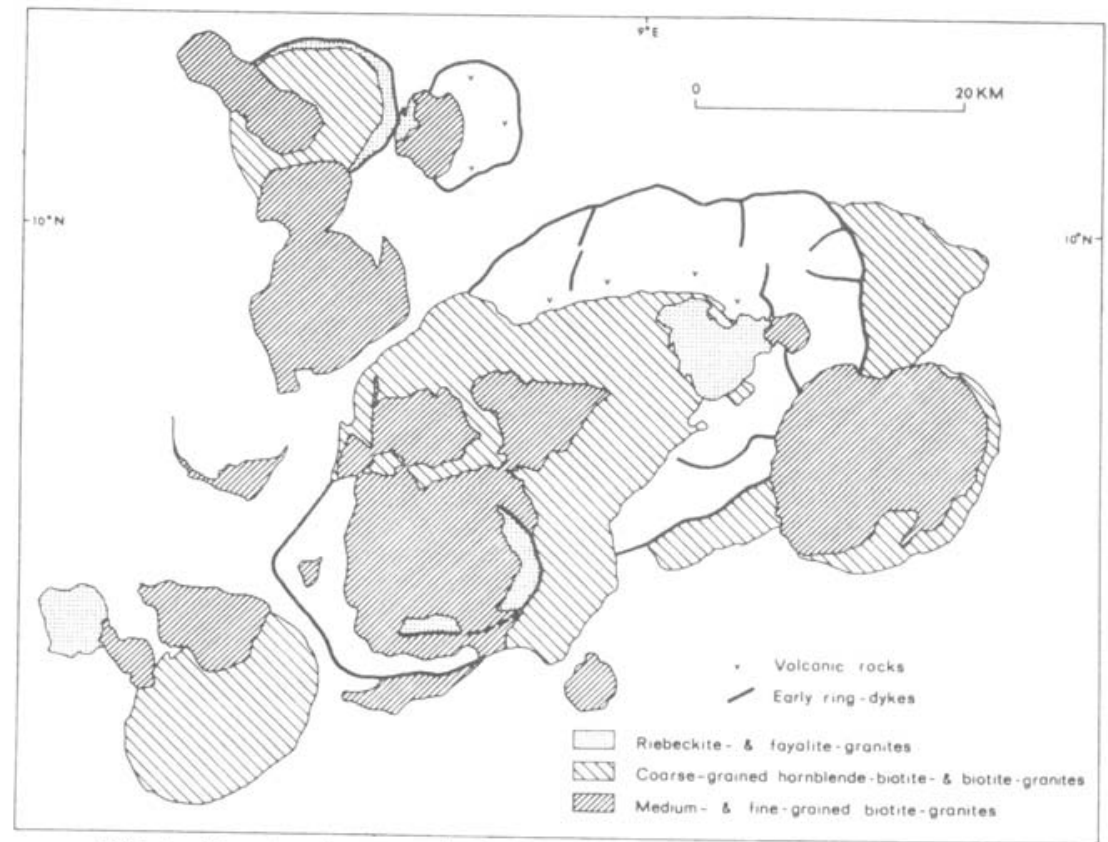

FIG. 1.-Structural patterns in the Jos-Bukuru and adjacent ring-complexes. Biotite-granite intrusions show discordant and cross-cutting relations to the
early ring-dykes. 
account for the outward dipping contacts and great thickness of granite indicated by the gravity survey.

This two-fold structural division is better seen in other non-orogenic igneous provinces. In the White Mountains of New Hampshire, ring-dyke complexes composed of syenite, monzonite, and hastingsite- and riebeckite-granite are invaded and partly obliterated by massive plutons of the Conway biotite-granite which are structurally independent of the ring centres (Billings, 1955). Similarly in the Permo-Carboniferous igneous province of the Georgetown Inlier, north Queensland, large cauldron subsidence areas containing rhyodacite welded tuffs and associated granitic ring-complexes are engulfed by widespread intrusions of biotite-adamellite-the Elizabeth Creek granitewhich are rarely controlled by the earlier pattern of ring faulting (Branch, 1966).

It is interesting to consider the petrogenetic implications for the Nigerian province. The early cylindrical ring-complex structures, together with the volcanic piles which they invade, were formed by fairly small volumes of magma, for screens of country rocks are common between successive intrusions. This magma, highly differentiated from the earliest stage-the granites are varied and the volcanic rocks have a similar range of composition, including peralkaline types-may be the product of limited fractional melting within the crust. Bailey \& Schairer (1966) have suggested that this process would be capable of producing peralkaline magma and Bowden (personal communication and MS, 1968) has shown that some geochemical features of the Nigerian granites indicate an origin by partial melting of crustal rocks. The massive late intrusions of biotite-granite, with a slight excess of alumina over alkalis, may represent a more complete melting of basement rocks, the larger volumes of magma allowing their emplacement to be independent of the structural controls followed by the earlier ring-intrusions.

\title{
REFERENCES
}

AJAKAIYE, D. E. 1968. A gravity interpretation of the Liruei Younger Granite ring complex of Northern Nigeria. Geol. Mag., 105, 256-263.

BAILEY, D. K. \& SCHAIRER, J. F. 1966. The system $\mathrm{Na}_{2} \mathrm{O}-\mathrm{Al}_{2} \mathrm{O}_{3}-\mathrm{Fe}_{2} \mathrm{O}_{3}-\mathrm{SiO}_{2}$ at 1 atmosphere, and the petrogenesis of alkaline rocks. J. Petrology, 7, 114-170.

BILLINGS, M. P. 1955. Geologic Map of New Hampshire. Scale 1:250,000 (U.S. Geological Survey).

BRANCH, C. D. 1966. Volcanic cauldrons, ring complexes, and associated granites of the Georgetown Inlier, Queensland. Bull. Bur. Miner. Resour. Geol. Geophys. Aust., No.76.

TURNER, D. C. 1963. Ring-structures in the Sara-Fier Younger Granite complex, Northern Nigeria. Q. Jl geol. Soc. Lond., 119, 345-361.

\author{
INSTITUTE OF GEOLOGICAL SCIENCES, \\ EXHIBITION ROAD, \\ LONDON, S.W.7. \\ 21st October, 1968.
}

\section{MICROFOSSILS FROM THE CLEAVED SKIDDAW SLATES OF MURTON PIKE AND BROWNBER (CROSS FELL INLIER)}

SIR,-Following on from the preliminary investigations of Wadge, Owens \& Downie (1967), one of the present authors (T.R.L.) has undertaken a palynological investigation of all the main outcrops of the Skiddaw Slates in the Cross Fell Inlier. This has been done in conjunction with the resurvey of the area by Messrs. A. J. Wadge and I. C. Burgess and an attempt has been made to establish a working stratigraphic succession to facilitate the geological mapping.

Microfossils (acritarchs and chitinozoa), hitherto recorded only from the Milburn and Ellergill Beds (referred on graptolite evidence to the $D$. bifidus Zone of the Llanvirn), 